\title{
First report of Globisporangium ultimum causing damping-off of wild rocket seedlings
}

\author{
Gelsomina Manganiello ${ }^{1}$ (D) Catello Pane $^{1}$
}

Received: 16 December 2020 / Accepted: 26 February 2021 / Published online: 8 March 2021

(c) Società Italiana di Patologia Vegetale (S.I.Pa.V.) 2021

Keywords Baby-leaf vegetables · Oomycetes $\cdot$ Plant diseases $\cdot$ Phytopathogens

Wild rocket (Diplotaxis tenuifolia (L.) DC.) is a cruciferous baby-leaf cultivated for ready-to-eat salads. In October 2020, survey of emerged seedlings (cv. Yeti) on raised beds under a plastic tunnel (Pontecagnano Faiano, Italy) revealed the occurrence of damping-off symptoms on about $30 \%$ of surface $\left(13{ }^{\circ} \mathrm{C} \leq \mathrm{T} \leq 24{ }^{\circ} \mathrm{C}, 66 \% \leq \mathrm{UR} \leq 90 \%\right)$. Disease started as root and crown rot until to the plants collapse; seedlings showed brown-dark rotted on collar and root deliquescence. Collar tissue $\left(2 \mathrm{~mm}^{2}\right)$ were surface-sterilized in $1 \%$ sodium hypochlorite, washed with sterile water, plated on PDA $+0.1 \%$ lactic acid, and incubated at $22 \pm 1{ }^{\circ} \mathrm{C}$ for 5 days. Microscopy (Nikon Eclipse $80 \mathrm{i}$; $40 \times$ magnification) revealed morphology of the oomycete Globisporangium ultimum (Trow) Uzuhashi, Tojo and Kakish. (syn. Pythium ultimum Trow) (van der Plaats-Niterink 1981; Uzuhashi et al. 2010) such as: aseptate mycelium, hyphal diameter of 3-7.36 $\mu \mathrm{m}$, spherical terminal hyphal swellings of $11.95-14.29 \mu \mathrm{m}$ along with intercalary sporangia of $14.62-22.73 \mu \mathrm{m}$. The molecular identification was performed by ITS1/ITS4 and DC6/ITS4 (White et al. 1990; Chen et al. 1992) region sequencing. Sequences of 789 and $1167 \mathrm{bp}$, respectively, were deposited in GenBank (accession numbers MW369642 and MW369641). BLAST analyses revealed $99 \%$ nucleotide similarity to previously published Pythium ultimum sequences (HQ643885.1, AY598657.2). Pathogenicity was assayed on 30 twoweek-old wild rocket seedlings by infecting the collar with $5 \mathrm{~mm}$ mycelium plugs obtained from one-week-old culture on PDA. Inoculated and non-inoculated plants were kept in growth chamber at $23{ }^{\circ} \mathrm{C}$. After 10 days, the isolate produced the same symptoms observed in the field, whereas control plants remained healthy. G. ultimum was re-isolated from the infected seedlings, confirming Koch's postulates and the pathogenicity on wild rocket. Despite Pythium damping-off has been previously observed on wild rockets in Italy (Gilardi et al. 2018), this is the first report in which molecular identification and Koch's postulates have been accomplished.

\section{References}

Chen W, Hoy JW, Schneider RW (1992) Species-specific polymorphisms in transcribed ribosomal DNA of five Pythium species. Exp Mycol 16:22-34

Gilardi G, Gullino ML, Garibaldi A (2018) Emerging foliar and soilborne pathogens of leafy vegetable crops: a possible threat to Europe. EPPO Bulletin 48(1):116-127

Uzuhashi S, Tojo M, Kakishima M (2010) Phylogeny of the genus Pythium and description of new genera. Mycoscience 51:337-365. https://doi.org/10.1007/s10267-010-0046-7

van der Plaats-Niterink AJ (1981) Monograph of the genus Pythium, vol 21. Centraalbureau voor Schimmelcultures, Baarn

White TJ, Bruns T, Lee SJWT, Taylor, J (1990) Amplification and direct sequencing of fungal ribosomal RNA genes for phylogenetics, in PCR protocols, ed J.M.S. Bartlett, D. Stirling, (Academic Press, Inc), 315-322

Publisher's Note Springer Nature remains neutral with regard to jurisdictional claims in published maps and institutional affiliations.
Gelsomina Manganiello

gelsomina.manganiello@crea.gov.it

1 Centro Di Ricerca Orticoltura E Florovivaismo, Consiglio Per La Ricerca in Agricoltura E L'Analisi Dell'Economia Agraria, Pontecagnano Faiano, Italy 